\title{
前立腺全摘除術における尖部処理の改良と術後尿禁制
}

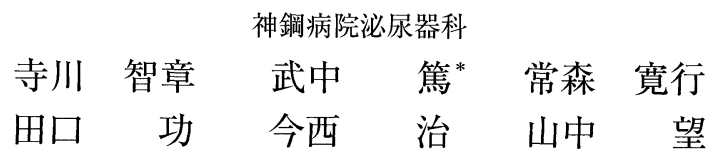

\section{MODIFICATIONS IN THE TECHNIQUE FOR APICAL DISSECTION OF RADICAL RETROPUBIC PROSTATECTOMY TO IMPROVE URINARY INCONTINENCE}

\author{
Tomoaki Terakawa, Atushi Takenaka, Hiroyuki Tunemori, \\ Isao Taguchi, Osamu Imanishi and Nozomu Yamanaka \\ From the Division of Urology, Shinko Hospital
}

(Purpose) To evaluate urinary continence after modified radical retropubic prostatectomy.

(Material and Methods) From March 1999 to May 2004, 110 patients with prostate cancer underwent radical retropubic prostatectomy. In all patients, the fascia of the levator ani was preserved, and the plane between the prostate and rectum was dissected prior to cutting the urethra. A modification to the technique of apical dissection was introduced in May 2002. The modified method included cutting the urethra along a precise line between the prostate and urethra following the shape of the prostatic apex. The grade of early urinary incontinence was analyzed by using the incontinence rate (urinary incontinence volume $(\mathrm{ml}) /$ total urinary volume $\times 100(\%)$ ). The incontinence rate was compared between the conventional and modified surgical techniques. Several other risk factors were also examined in these patients. Continence rates were analyzed among the patients over a one-year postoperative course.

(Results) The incontinence rate on the day, the next day and 5-7 days after the removal of the urethral catheter were $18.1 \%, 11.2 \%, 6.0 \%$ in the modified group, and $36.6 \%, 22.5 \%, 12.6 \%$ in the conventional group, respectively. With the introduction of this modified method, the incontinence rate was significantly decreased $(\mathrm{P}<0.005)$. Complete continence rates 3 and 12 months after the operation were $81.3 \%$ and $98.3 \%$ in the modified and $60.0 \%$ and $97.8 \%$ in the conventional group. The time to regain complete continence in the modified was earlier than that in the conventional. After oneyear, the rate of complete continence was similar and a satisfactory average in each group.

Except for surgical techniques, no other factors were associated with a risk of incontinence statistically.

(Conclusions) We recommend modified apical dissection to preserve the urethral striated sphincter, which can be useful in improving the early incontinence rate and the recovery of continence.

Key words : Radical prostatectomy, urinary incontinence, prostatic apex

要旨：(目的）根治的恥骨後式前立腺摘除術（RRP）後の尿禁制につき手術方法に関し検討した.

（対象と方法）RRP を施行した 110 例を対象とした. 前立腺尖部へのアプローチにつき改良術式を導

入した前後で 2 群（A 群 ; 従来法 49 例, B 群 ; 改良法 61 例）に分け, 他の臨床病理学的因子とともに

尿禁制との関係を検討した. 両群とも, (1) 肛門挙筋筋膜を温存し, (2) 前立腺側方処理を先行させた.

B 群では尖部に併存する前立腺肥大症の形態に応じて尿道を切断する操作を追加した.

*現 川崎医科大学泌尿器科 
(結果) 自排尿開始から 1 日目，2 日目，5７日目の尿失禁量率 (1 日尿失禁量/ 1 日全尿量) は A 群 : $36.6 \%, 22.5 \%, 12.6 \%, \mathrm{~B}$ 群 : $18.1 \%, 11.2 \%, 6.0 \%$ と B 群で有意に低值を示した $(\mathrm{P}<0.05)$. 術後 3 力月後の完全尿禁制率も A 群 $60.0 \%, B$ 群 $81.3 \%$ と B 群で早期に尿禁制が回復したが $(\mathrm{P}<0.05), 12$ カ月後ではそれぞれ $97.8 \%, 98.3 \%$ とほぼ同等であった. なお, 他の因子と尿禁制に関する相関は認めな かった.

（結論）前立腺尖部に的確にアプローチし, 尖部の形態に応じて正しい尿道切断面を得ることで, 短期 尿禁制及び尿禁制回復期間が著明に改善される可能性が示唆された.

キーワード：根治的前立腺全摘除術，術後尿失禁，前立腺尖部

\section{緒言}

前立腺癌に対する根治的前立腺全摘術後の尿失禁 は，患者の QOL を損なう重要な問題である1).アプ ローチの方法としてもっとも普及している䎵骨後式前 立腺全摘除術（以下，RRP と略す）の術後尿禁制率は 69 95\% 程度であるが2) ，報告によりその定義や評 価方法が異なっているため現時点でも実態は不明と言 わざるを得ない. 多くの報告では術後 6 カ月から 1 年 後にパッドを必要としているか否かで尿禁制を評価し ているが，長期的に良好な尿禁制が得られても，手術 直後からの短期的尿禁制が不良である場合は QOLを 著しく低下させる可能性があることから尿禁制の回復 過程を評価することも重要と思われる，そこで短期的 尿禁制を客観的かつ確実に評価するために，手術直後 の実測值に基づく一日尿失禁量率（一日全尿失禁量： 1 日全尿量）を採用した.

一方, RRPにおいては様々な因子が術後尿失禁に多 元的に関与していると考えられているが, 特に膜様部 尿道へのアプローチや尿道切断方法の改良により術後
尿禁制の改善が認められたとする報告が多い. しかし, 前立腺周辺は解剖学的個体差が著しく, 画一的な手術 方法を確立することは非常に困難である．我々は従来 から肍門挙筋筋膜の RRP における意義に着目し, 長期 尿禁制については満足すべき成績が得られていたが, さらに術式を改良することにより短期的尿禁制も飛躍 的に向上している. 今回我々は, 術式の妥当性を尿失 禁量率（短期尿禁制）および経時的な尿禁制率（長期 尿禁制）により検討し，若干の知見が得られたので報 告する.

\section{対象}

1990 年 1 月から 2004 年 5 月までの間に神鋼病院泌 尿器科において前立腺癌に対して根治的恥骨後式前立 腺全摘除術を施行した 168 症例の内, 1999 年 3 月以降 に手術方法として側方先行処理を採用し，かつ短期的 尿失禁量を実測し得た 110 例を対象とした。 これらの 症例を前立腺尖部へのアプローチにつき改良術式を導 入した前後で 2 群 (A 群; 従来の方法, B 群; 改良法) に分類し, 比較検討した. A 群は 1999 年 3 月から 2002

Table 1 Clinical profile of patients

\begin{tabular}{l|c|c|l}
\hline & A & B & P-value \\
& (Mar 1999-Apr 2002) & (May 2002-May 2004) & \\
\hline No. patients & 49 & 61 & NS $*$ \\
Age & $67.1 \pm 5.4$ & $66.8 \pm 6.2$ & NS ** \\
PSA & $8.3(3.1-61.6)$ & $9.6(3.4-134)$ & NS *** \\
Neoadjuvant endocrine therapy & & & \\
with & 14 & $38 * * *$ \\
without & 35 & 23 & \\
Clinical T stage & 14 & 16 & \\
T1c & 22 & 13 & \\
T2a & 8 & 4 & \\
T2b & 4 & 1 & \\
T3a & 1 & & \\
T3b & & & \\
\hline
\end{tabular}

* Student's t-test, $* *$ Welch's t-test, $* * *$ chi-square test for independence, $* * * * 1 \times \mathrm{m}$ contingency table 
Fig. 1 術中所見

a. 肛門挙筋筋膜に包まれたままの状態で，LA を lateral pelvic fascia から剥離する.

LA (肛門挙筋)， P (前立腺)

b. 前立腺尖部の処理 : 前立腺後面にペンローズドレーンを通し，尖部を腹側に挙上し ている. U(尿道)

c. 尿道前面の切断 : 前立腺尖部の形態に沿って剥離, 尿道の腹側を切開したところ. 膀胱吻合に備えて 11 時, 1 時の位置に吸収糸を運針しておく. $\mathrm{BC}$ (バルーンカテー テル)

d. 尿道後面の切断：尿道および括約筋複合体を完全に切断．5時， 7 時の位置にも膀 胱吻合用吸収糸を運針しておく。
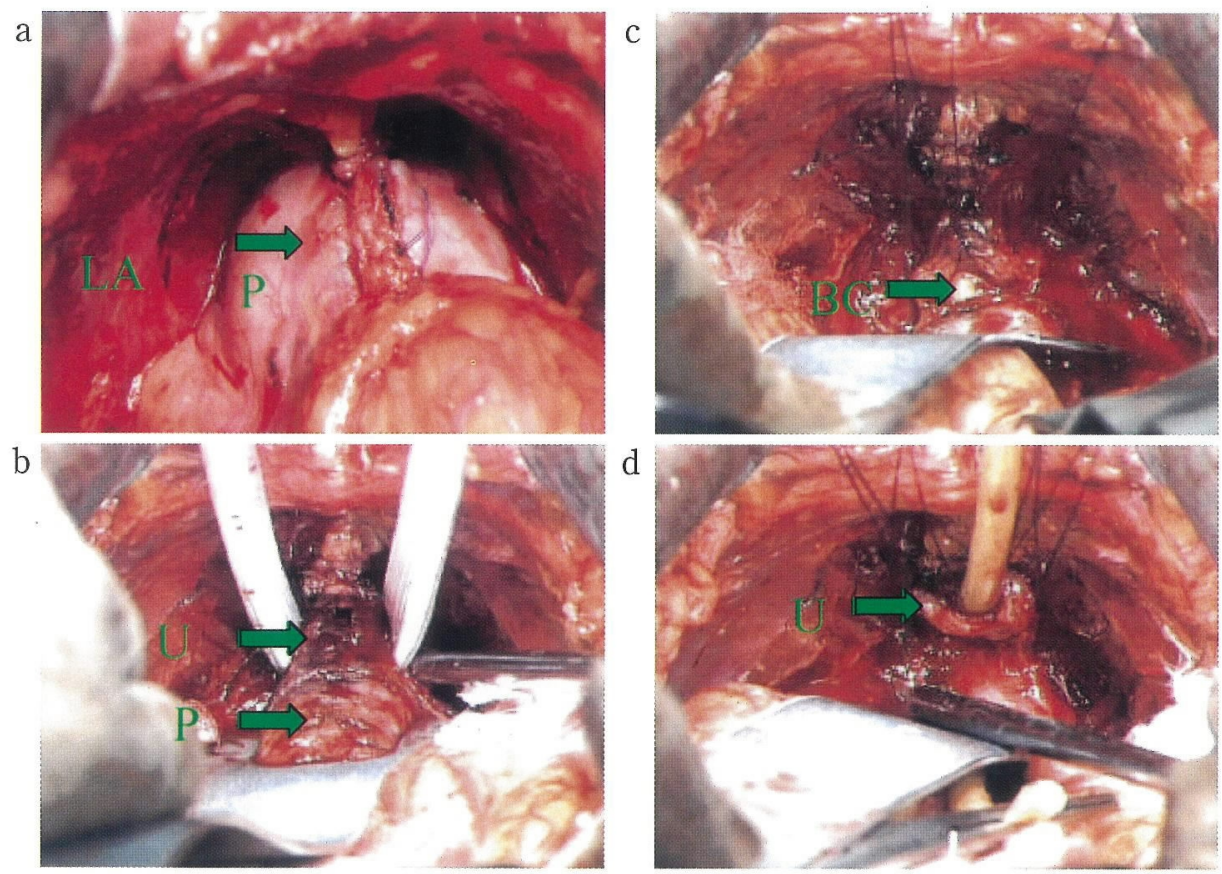

年 4 月までに施行した 49 例，B 群は 2002 年 5 月から 2004 年 5 月までに施行した 61 例である（Table 1).

\section{方法}

\section{1. 手術方法}

手術は全例 N.Y.もしくはN.Y.の指導により行われ た.

（1）内骨盤筋膜の切開, deep dorsal vein complex (以下, DVC と略す) の切断

内骨盤筋膜の前面を覆う脂肪を丁寧に除去し, 深陰 荎背静脈の表在枝定切断する。前立腺側面を内側に強 く押すと, 直腸周囲の脂肪組織が透見される。内骨盤 筋膜の折り返しからメッチェンバウムを用いて内骨盤 筋膜のみを直腸周囲脂肪組織の方向に切開すると, 肛 門挙筋の表面を覆う非常に薄い筋膜（肛門挙筋筋膜；

以下，FLA と略す)を同定できる，FLAに包まれたま まの状態で，肛門挙筋を lateral pelvic fascia から外側 に押しやるように剥離をすす好 (Fig. 1-a). 解剖学的 個体差によりFLA を温存できない場合は，FLAの内 側 (内骨盤筋膜) のラインで展開するが，極力肛門挙 筋を損傷しないように心がける。続いて，内骨盤筋膜 の切開線を恥骨前立腺勒带まで延長し, 恥骨前立腺靳 带を切離する。

（2）DVCの処理および前立腺側方先行処理

Bunching techniqueにより Santorini 静脈叢を収束 結柏後, 前立腺尖部尿道移行部とDVCの間の avascular plane に直角ケリーを通し尿道直上で DVC 全体を 結紫切断する. 正しい面での処理が行われると, 前立 腺尖部において外尿道括約筋に包まれた尿道が明瞭に 
Fig. 2 正確な尿道切断面の同定

$\mathrm{P}$ (前立腺), $\mathrm{Bl}$ (膀胱), SV (精囊)

前立腺を十分に頭側に裁引することで, 前立腺尖部の湾曲に沿って尿道を切断できる。

A群: 従来法

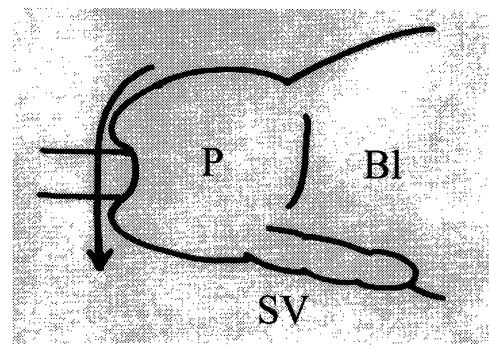

B群: 改良法

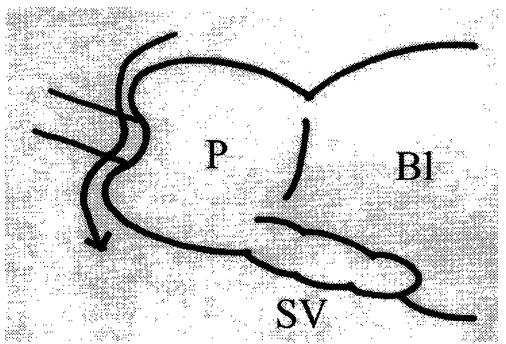

観察される。ここで前立腺側方を観察し NVBを同定 する. 神経温存の場合はNVBのやや上方, 温存を企図 しない場合はNVBと直腸の間で lateral pelvic fascia を切開する。この切開縁から前立腺と直腸の間を手指 にて鈍的に剥離・展開し（側方先行処理：Fig. 1-b), 前立腺に十分な可動性を持たせる。

（3）尿道切断方法

A 群 : 従来法

前立腺尖部において尿道に対しほぼ垂直方向にアプ ローチし，尿道を切断する。 このとき，Walshらの方 法 ${ }^{8)}$ 準じ膀胱尿道吻合用の吸収糸 (2-0モノクリル)を 4 力所運針しておく (Fig. 1-c).

B 群 : 改良法

尿道べラ（自作）を使用して前立腺を十分に頭側に 牽引すると, 前立腺尿道移行部前面の良好な視野が得 られる.ここで前立腺尖部の形状をよく観察し，その 湾曲に沿いながら尿道に達し，これを切断する．尖部 腹側における肥大症が大きい場合は前立腺内（精阜付 近）まで戻って切断するようなイメージになる（Fig. 2). あらかじめ挿入しているバルーンカテーテルを中 間の適切な位置で切断し，その断端を上下に引きつつ 尿道後面を尿道前面と同じレベルで直角鉗子にてすく い, 鋭的に切断する. 神経血管束を合併切除するとき はこの時点で処理する. 先に展開しておいた前立腺直 腸間隙に手指を挿入して前立腺尖部後面の鈍的剥離を 進めつつ尖部後面の肥大症の程度を触診にて把握する (Fig. 3). 尖部をやや頭側に引き起こすと, 尖部の肥大 症の程度にかかわらず, striated sphincter complex の切断レベルが明瞭に観察されるので，これを鋭的に 切断する．尿道への運針は従来法と同様である．尿道
Fig. 3 尿道後面の処理

$\mathrm{P}$ (前立腺), $\mathrm{U}$ (尿道), arrow (striated sphincter complex)

前立腺直腸間隙に手指を挿入し, 尖部後面の肥大 症の程度を触診する. 尖部後面をやや頭側に引き起 こすと, striated sphincter complex の切断レベル が把握される.

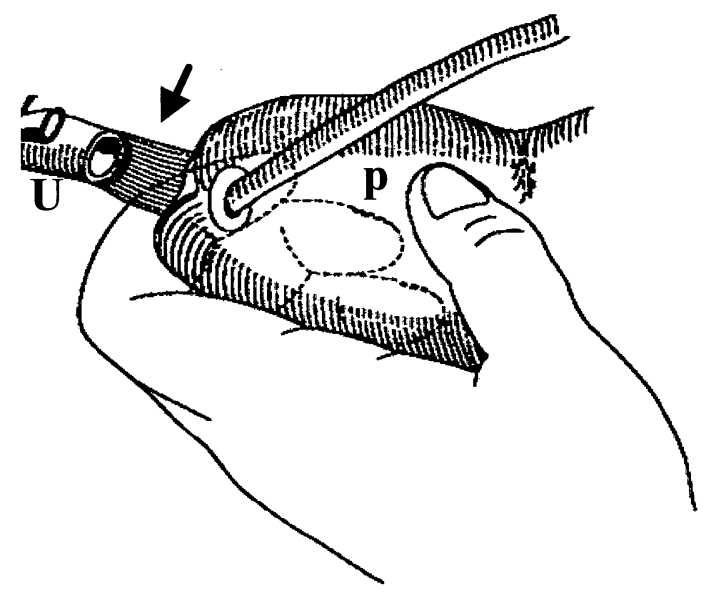

切断面を観察すると, 十分な尿道の長さが保たれてい ることがわかる (Fig. 1-d). 改良法ではこのような操 作により, 前立腺尖部に併存する肥大症の程度に応じ て, 正しい尿道切断面を同定することがポイントであ る.

2. 尿禁制の評価方法

（1）短期的尿禁制

Pad を用いて尿失禁量を実測し，尿失禁量率 (\%)を 次のように定義した. 
Table 2 Clinical outcome

\begin{tabular}{l|c|c|c}
\hline & A & B & P-value \\
& (May 1999-Apr 2002) & (May 2002-May 2004) & \\
\hline No. patients & 49 & 61 & NS * \\
Opetrating time (min) & $256.3 \pm 50.2$ & $240.3 \pm 57.5$ & $\mathrm{p}=0.008 * *$ \\
Blood loss (cc) & $1,064 \pm 527$ & $817 \pm 405$ & NS ** \\
Pathological T stage & & 1 & \\
T0 & 2 & 1 & \\
T1 & 7 & 18 & \\
T2a & 24 & 23 & \\
T2b & 13 & 11 & \\
T3a & 2 & 7 & \\
T3b & 1 & 0 & \\
T4 & & & \\
\hline
\end{tabular}

* Student's t-test, $* *$ Welch's t-test, $* * * 1 \times \mathrm{m}$ contingency table

尿失禁量率 $(\%)=\frac{1 \text { 日尿失禁量 }(\mathrm{g})}{1 \text { 日全尿量 }(\mathrm{g})} \times 100$

A，B群において，自排尿開始から 1 日目 (DAY1)， 2 日目（DAY2），5７ 日目（DAY5〜7）の尿失禁量率 と年齢, BMI, 初診時 PSA, 術前ホルモン療法の有無, 病理学的病期, NVB 温存の有無, 手術手技との相関を 統計学的に検討した，有意差の検定には unpaired t-testを用い, 統計学的に $\mathrm{p}<0.05$ を有意差ありとし た.

(2) 手術方法別長期的尿禁制

術後 1 年以上観察し得た $\mathrm{A}$ 群 45 例, B 群 59 例につ いて 3 力月後, 6 力月後, 12 力月後の尿禁制を便宜的 に2つ (Category I : 完全尿禁制 (pad 不要), 補足; ごくまれにごく少量の尿失禁があったとしても，Pad を使用しないと申告した患者はこの category に含ま れる. Category II : Category I 以外, 補足 ; (a)ごく少 量の尿失禁が毎日あるが Pad は使用しない，厚手の下 着やティッシュペーパーにて対応している. (b) ほと んど尿失禁はないが，ふいにズボンが濡れるほどのや や多量の尿失禁があるので，外出時には念のため $\mathrm{Pad}$ を使用する. (c) 失禁があり, pad を使用する。このよ うな症例がこの Categoryに含まれる.）に分類し検討 した.

Pad を要しているかどうかは，患者の申告により判 定した.

\section{結果}

年齢, 初診時 PSA 值, 術前内分泌療法の有無, 臨床 病期, 病理学的病期に扮ける分布の偏りについては A， B 群とも統計学的に有意差を認めなかった．両群
とも手術時間に有意差は認められなかったが, 出血量 はB 群が有意に少なかった（Table 2)。この差異は主 として側方先行処理にかかわる learning curve と推定 されるが，前立腺側方には continence zone がないこ とから, 術後尿禁制には直接的な影響はないと考えて いる. 側方先行に関する尖部断端陽性率に関しては, $\mathrm{B}$ 群では前立腺尖部の処理方法が $\mathrm{A}$ 群と異なるが両 群で有意差を認めなかった $(\mathrm{p}=0.366)$.

DAY1，DAY2，DAY5７における尿失禁量率は, A 群で $36.6 \%, 22.5 \%, 12.6 \%, B$ 群で $18.1 \%, 11.2 \%$, 6.0\% であった (Fig. 4). B 群は A 群と比較して尿失禁 量率は早期に著明に低下しており，DAY1，DAY2, DAY5〜7 のすべてにおいて統計学的に有意差を認め た $(\mathrm{p}<0.05)$ 。 な㧍，退院時（DAY5７）の完全尿禁 制 (Category I) は, A 群 : $35.4 \%, B$ 群 : $53.3 \%$ であっ た. 手術手技以外の因子と尿禁制率に関しては統計学 的に有意な相関は認められなかった（Table 3).

術後 3,6,12 力月後の完全尿禁制率 (Category I) は それぞれ A 群 : 60.0\%, 91.1\%, 97.8\%，B 群：81.3\%， 93.2\%，98.3\% であった (Fig. 5). 12 力月後の完全尿禁 制は $\mathrm{A}$ 群, B 群ともほぼ同等であったが， 3 カ月後に $\mathrm{A}$ 群の $60.0 \%$ に対し B 群では $81.3 \%$ と早期に尿禁制 が回復していた（P=0.020）.

\section{考察}

限局性前立腺癌に対する恥骨後式根治的前立腺全摘 除術は, 1980年代の Walsh らの anatomical approach ${ }^{9}$ や Myers $ら^{10)} の$ bunching technique の開発により安 全性が確立され，死亡率の少ない忍容性に優れた術式 として定着した. 臨床的限局癌に対して IMRT や粒子 
Fig. 4 術後短期の尿失禁量率
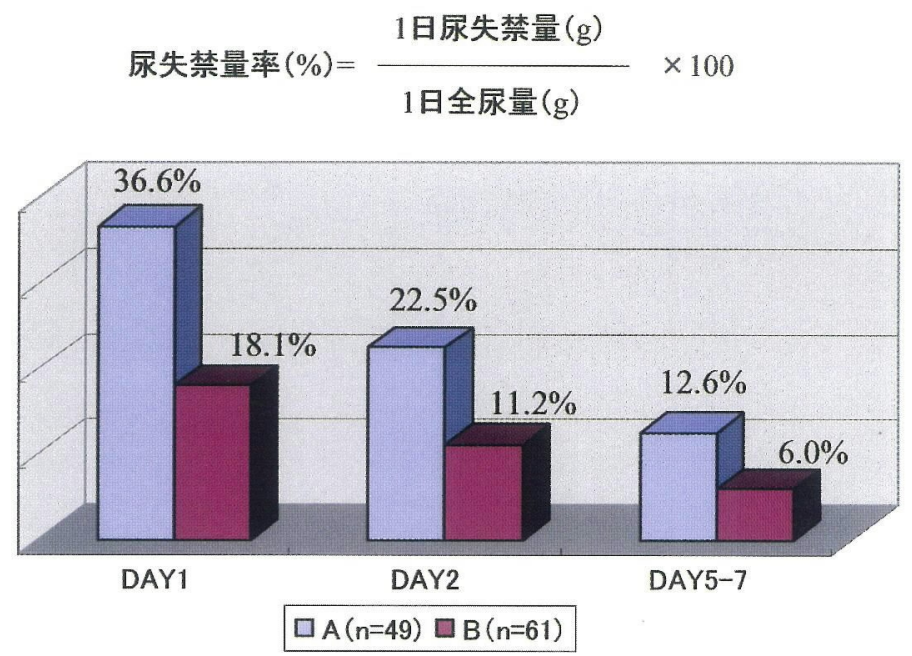

Table 3 Analysis of risk factors for incontinence after radical prostatectomy

\begin{tabular}{l|c|c|c}
\hline \multirow{2}{*}{} & \multicolumn{3}{|c}{ P-value } \\
\cline { 2 - 4 } & Day 1 & Day 2 & Day 5-7 \\
\hline Age $(66.9 \pm 5.89) \quad(66 \geqq$ or $67 \leqq)$ & 0.480 & 0.612 & 0.880 \\
BMI $(23.9 \pm 3.17)(24>$ or $24<)$ & 0.289 & 0.196 & 0.418 \\
PSA $(3.1 \sim 134)(10>$ or $10 \leqq)$ & 0.102 & 0.300 & 0.111 \\
NVB preservation (yes or no) & 0.974 & 0.640 & 0.109 \\
Neoadjuvant endcrine therapy (yes or no) & 0.974 & 0.599 & 0.109 \\
Pathological T stage (T1/T2 or T3/T4) & 0.591 & 0.741 & 0.976 \\
\hline
\end{tabular}

Fig. 5 手術方法別術後長期の尿禁制

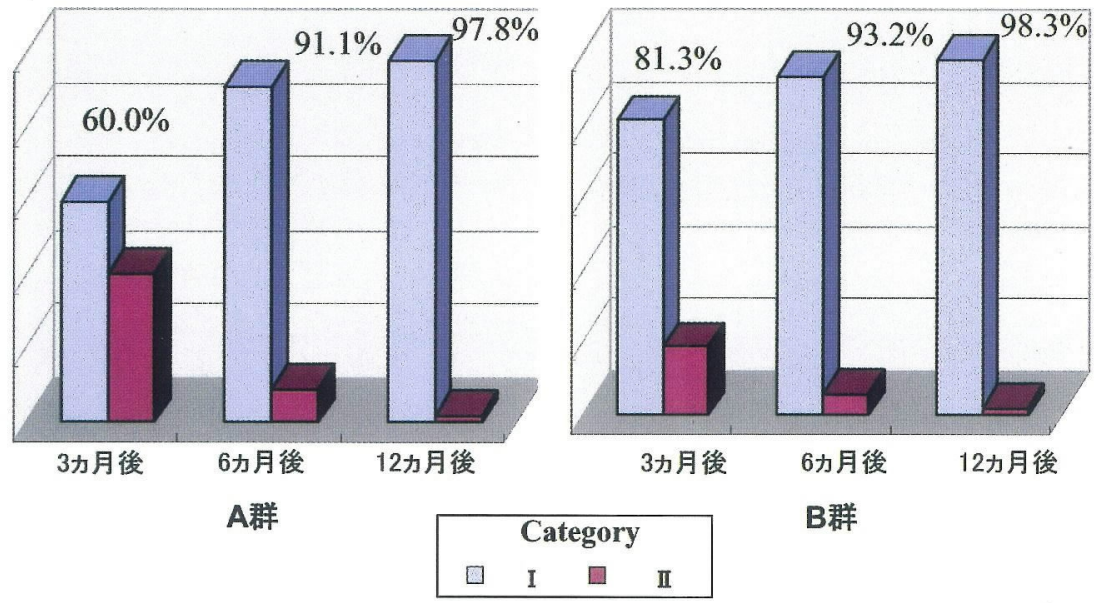


線治療などの新しい放射線治療の開発や進歩にもかか わらず本術式が gold standard として広く普及してい る背景には, 術後に詳細な病理組織学的検索を行うこ とができることや, 病理組織学的リスクに基づくノモ グラムから再発率を予測することが可能であることな どがあげられる.しかし, 術後の尿失禁, 性機能障害, 尿道狭窄などの有害事象は, 治癒切除が達成されたと しても患者の QOL を損ない，満足度を低下させる可 能性がある. 特に, 尿失禁は術後 QOL 低下の最も重要 な要因と考えられることから，ょり慎重な評価と対策 が期待される.

術後尿禁制に関する過去の報告を見ると,その定義, 評価時期, 評価方法（担当医の面接, 患者調査) など についての一定の基準はなく, 客観的な評価は極めて 困難である2) 77. Pad が必要である症例, あるいは Pad の一日使用量が 3 枚以上必要である場合を尿失禁と定 義している施設が多いが，このような定義にしても担 当医の面接調査かアンケート調查かによって成績が異 なることは当然と思われる. 評価時期については術後 6 力月， 12 力月， 24 力月での調查報告が多い.また, 尿禁制は術後 2 年まで改善するとの報告があり ${ }^{2)}$, こ の間の長期にわたる QOL 低下を考慮して, 尿失禁回 復までの期間（中央値）を評価した報告もある.

一般に, 術後の尿失禁は手術直後（尿道留置カテー テル拢去時点）には，1 日尿量の 0 $50 \%$ 程度認めら れ, 徐々に淵減し $1 \sim 2$ 年程度で固定すると考えられて いる. 加えて, 一旦完全な尿禁制が獲得された後は, 術後放射線照射や加齢あるいは神経因性膀胱の合併な ど，他の因子がない限り悪化することはない．このよ うな考方方から我々は短期的尿禁制を尿失禁量の実測 值により評価するとともに, 術後 3 カ月, 6 力月, 12 カ月後の長期尿禁制について調査した．この結果，今 回対象とした 110 例では術後 12 力月後の時点で $98.1 \%$ の完全尿禁制が得られており, 過去の報告2) 7) と 比較して極めて良好な結果が得られた。 さらに，手術 方法を改良 (B 群)することにより短期的尿失禁量率が 有意に減少し, 退院時に $53.3 \%$ の完全尿禁制が得られ たのみならず，比較的早期に尿禁制が回復することが 明らかになった。

術後尿禁制に影響を及ほすす要因として, 臨床病期, 病理学的病期, 出血量, 患者の年齢, 手術手技, 神経 血管束温存の有無など様々な因子が検討されてきた が，少なくとも現時点ではいかに機能的尿道長を保持 するかが最も重要であること ${ }^{11122}$ は議論の余地がな
い. 今回の我々の検討でも, 手術方法の改良以外に統 計学的有意差は見いだせなかった。 さらに, 術者の技 術やその成熟度により大きく左右されることも否定で きない事実で13), 同一の施設や術者であっても, 手術 方法の改良により尿禁制の成績は著しく改良されてき ている.

Myers ${ }^{14)}$ は男性の urinary continence zone として, Superior sphincter-vesical neck (preprostatic) sphincter, Inferior sphincter-sphincteric urethra, Levator ani の三点をあげており, 現時点ではその妥当性につ いて一応のコンセンサスが得られていると思われる。 実際の手術では Superior sphincter はほとんどの機能 が失われるので, (1) 肛門挙筋の損傷を避けること (2) DVC を切断する際に尿道括約筋腹側の損傷を避ける こと (3) 正確に尿道切断面を同定することの 3 点が特 に重要と思われる. 以下, これらの項目について考察 を加える。

（1）肛門挙筋の損傷を避けること

能動的尿禁制は前立腺尖部および膜様部尿道を取り 囲む肛門挙筋が重要な役割をはたしていると考えられ ており，これらは陰部神経により支配されている.

一方, Narayan $ら^{15)}$ は cadaver による解剖学的検討 を行い, 前立腺尖部から陰部神経の尿道枝までの距離 は 3 13mm であり, そのうち半数は片側のみに同定 され，雨側であってもわずか一本の分枝しか認められ なかったとしている. 我々は 8 体の fresh cadaverに おいて RRP の手術模倣を施行し解剖学的な検討をし たところ, 全例において陰部神経から尿道括約筋に分 枝する尿道枝を同定した ${ }^{16)}$. また, FLA 下端からその 尿道枝までの距離を測定したところ, その距離は 3〜 $8 \mathrm{~mm}$ (平均 5.5mm) であり (Fig. 5), 非常に短い場合 は手術中にこれを損傷しうることを明らかにした。手 術中にこれらの神経経路を見ることはないが, この損 傷を回避するためには FLA をうまく同定する作業が 大切である. 実際の手術においては, 内骨盤筋膜を切 開する位置を前立腺の外側縁ぎりきり設定し，メッ チェンバウムなどで丁寧に切開すると肛門挙筋繊維を 露出・断列させることなくFLA を同定することがで きる. Fresh cadaver を用いた解剖学的所見より, FLA は骨盤底を形成するプレートと考えられるので16), FLA に包まれたまま lateral pelvic fascia から肛門挙 筋を剥離することは陰部神経の尿道枝や肛門挙筋の continence mechanism を温存するためにも極めて合 目的かつ重要な操作である.われわれは従来から（A 
群，B 群とも)この方法を採用しており，長期的尿禁制 の向上に寄与していると考えられた.

（2）DVC 切断時に尿道腹側の損傷を避けること

Walsh はDVCを切断するために bunching technique を行うと尿道括約筋が切除標本に引き込まれる ことから,この方法を行わず, DVC と恥骨結合を一括 して結杽し，鋭的に切断する方法を推奨している ${ }^{8}$. 荒井らも ${ }^{17)}$ 従来のWalsh らのいわゆる三角間隙に直 角鉗子を通す方法を否定し, DVC を無結紮で鋭的に切 断する方法を採用している。しかし，我々は bunching techniqueに引き続いて三角間隙に直角鉗子を通し，

DVC を電気メスにて切断しているが, 術後の尿禁制は きわめて良好に維持されている，勿論，三角間隙に直 角鉗子を通す際には，尿道腹側の損傷を避けるために 慎重な操作とある程度の熟練を要するが，少なくとも DVC そのものに括約筋機能は存在しないと考えてい る. 武中によれば fresh cadaverによる手術模倣で, 同 様に三角間隙に直角鉗子を通す方法をとっても，外括 約筋の損傷は認められなかったという（私信）.

（3）正確な尿道切断面の同定

最近, 放射線治療において, 前立腺が 1 〜 $18 \mathrm{~mm}$ の可 動性を有すること ${ }^{1819)}$ が明らかにされてきたが，前立 腺全摘の場合は, 前立腺を周辺の構造物から可及的に 剥離することにより，さらに可動域を拡大することが 可能である. 我々が採用している側方先行術式は DVC を切断した後, 前立腺の側方と後面を剥離・展開して おくことにより前立腺の可動性を良好にし，前立腺尖 部を膀胱側に毫引することにより尿道を通常より $1.0 \sim 1.5 \mathrm{~cm}$ 程度膀胱側に引き出すことが可能となる (Fig.1-b). さらに最近の方法（B 法）では, Myers の説に従い, 尖部に併存する前立腺肥大症の程度に応 じて正しい尿道切断面を同定することを意識してい る. すなわち, 前立腺は特に尖部において併存する肥 大症の占拠部位，およびサイズにより非常に形態学的 多様性に富み，その前立腺尖部が continence zone (inferior sphincter) と overlap する場合があるので, 尖部 の位置でそのまま尿道を切断する，もしくは尖部より やや distal 側で尿道を切断するという従来の考え方で は, 症例によっては尿禁制に関与する continence zone （inferior sphincter）を一部損傷する可能性がある．実 際の手術においては, 側方先行処理により前立腺に可 動性を持たせ, 前立腺尿道移行部の腹側においては尿 道べラ（自作）を使用して前立腺を十分に頭側に牽引 すること，さらに後面においては前立腺直腸間隙に手
指を挿入して前立腺尖部後面をやや頭側に引き起こす ことなどの操作により, overlap した continence zone (inferior sphincter) の損傷を回避することができると 考えられる. 以上の操作により機能的尿道長を十分に 確保することは，今回の検討から長期的尿禁制よりむ しろ短期尿禁制や尿禁制回復の短縮化に寄与している ことが示唆された。なお，これらの手術操作の改良を 行っても切断端陽性率には影響を及ぼさなかった。

術後尿失禁には本論文で述べた以外にも術後出血, 尿道膀胱吻合による尿道損傷, 尿道膀胱縫合不全, 尿 道狭窄などのいくつかの要素が関与している可能性が ある、今後さらに症例を重ね, 短期的尿禁制率の向上 を目指したい．

\section{結 語}

1， RRP 術後の短期的尿禁制を客観的かつ確実に評 価するために，手術直後の実測值に基づく一日尿失禁 量率（一日全尿失禁量 $\div$ 一日全尿量）を採用し, 検討 した.

2 , 手術手技以外の因子と尿禁制との相関は認めら れなかった。

3, 今回対象とした 110 例 (A 群 $+\mathrm{B}$ 群) では術後 12 カ月の時点で $98.1 \%$ の完全尿禁制が得られた. 手術中 にFLA を意識し，陰部神経の尿道枝や肚門挙筋を損 傷しないことが長期尿禁制の向上に寄与していると考 えられた。

4, 手術方法を改良 (B 群) することにより短期的尿 失禁量率が有意に減少し, 退院時に $53.3 \%$ の完全尿禁 制が得られたのみならず，比較的早期に尿禁制が回復 した．手術改良の要点は前立腺に可動性をもたせるこ とにより，機能的尿道長を可及的に温存することにあ る.

\section{文献}

1) Fowler, F.J., Barry, M.J., LuYao, G., Wasson, J., Roman, A. and Wennberg, J. : Patient-reported complications and follow-up treatment after radical prostatectomy. Urology., 42, 622-628, 1993.

2) Steiner, M.S., Morton, R.A. and Walsh, P.C. : Impact of anatomical radical prostatectomy on urinary continence. J. Urol., 145 (3), 512-4, 1991.

3) Zincke, H., Oesterling, J.E., Blute, M.L., Bergstralh, E.J. and Myers, R.P. : Long-term (15 years) results after radical prostatectomy for clinically localized (stage T2c or lower) prostate cancer. J. Urol., 152, 1850-1857, 1994.

4) Catalona, W.J., Carvalhal, G.F., Mager, D.E. and Smith D.S. : Potency, continence and complication 
rates in 1870 consecutive radical retropubic prostatectomies. J. Urol., 162, 433-438, 1999.

5) Eastham, J.A., Kattan, M.W., Roger, E., Goad, J.R., Ohori, M., Boone, T.B. and Scardino, P.T. : Risk factors for urinary incontinence after radical prostatectomy. J. Urol., 156, 1707-1713, 1996.

6) Murphy, G.P., Mettlin, C., Menck, H., Winchester D.P., Davidson, A.M. : National patterns of prostate cancer treatment by radical prostatectomy : results of a survey by the American college of surgeons commission on cancer. J. Urol., 152, 1817-1819, 1994

7) Fowler. F.J., Barry, M.J., LuYao, G., Wasson, J., Roman, A. and Wennberg, J. : Effect of radical prostatectomy on patient quality of life : results from a Medicare survey. Urology., 45, 1007-1015, 1995.

8) Walsh, P.C. : Anatomic radical retropubic prostatectomy. In Campbell's Urology, 8 th ed., p 3107-3129, Saunders Co., Philadelphia, 2002.

9) Walsh, P.C. : Radical retropubic prostatectomy. In Campbell's Urology, 5th ed., p2754-2775, Saunders Co., Philadelphia, 1986.

10) Myers, R.P.: Improving the exposure of the prostate in radical retropubic prostatectomy. : Longitudinal bunching of the deep venous plexus. J. Urol., 142, 1282-84, 1989.

11) Coakley, F.V., Eberhardt, S., Kattan, M.W., Wei, D. C., Scardino, P.T. and Hricak, H. : Urinary continence after radical retropubic prostatectomy : relationship with membranous urethral length on preoperative endorectal magnetic resonance imaging. J. Urol., 168, 1032-1035, 2002.

12) Hammerer, P. and Huland, H. : Urodynamic evaluation of changes in urinary control after retropu- bic prostatectomy. J. Urol., 157, 233-236, 1997.

13) Walsh, P.C., Marschke, P., Ricker, D. and Burnett, A.L. : Patient-reported urinary continence and sexual function after anatomical radical prostatectomy. Urology, 55 (1), 58-61, 2000.

14) Myers, R.P. : Practical surgical anatomy for radical prostatectomy. Urol Clin North Am, 28, 473490, 2001.

15) Narayan, P., Konety, B., Aslam, K., Aboseif, S., Blumenfeld, W. and Tanagho, E. : Neuroanatomy of the external urethral sphincter : implication for urinary continence preservation during radical prostate surgery. J. Urol., 153, 337-341, 1995.

16) Takenaka, A., Hara, R., Soga, H., Murakami, G. and Fujisawa, M. : A novel technique for approaching the endopelvic fascia in retropubic radical prostatectomy, based on an anatomical study of fixed of and fresh cadavers. BJU int., 95 (6), 766-71, 2005.

17）荒井陽一：前立腺全摘除術一前立腺尖部の展 開一. 臨泌, 55, 227-233, 2001.

18) Shimizu, S., Shirato, H., Kitamura, K., Shinohara, N., Harabayashi, T., Tsukamoto, T., Koyanagi, T. and Miyasaka, K. : Use of implanted marker and real-time tracking of the marker for the positioning of prostate and bladder cancer. Int J Radiat Oncol Biol Phys, 48, 1591-1597, 2000.

19）武田繁雄, 島田 治, 佃 文夫, 乾 政志, 桑田 善弘, 筧 善行：マーカー金球による位置補正を 併用した前立腺 3 次元原体照射療法 (3D-CRT) の 照射法と短期的安全性. 泌尿紀要, 50,611-616, 2004.

(2005 年 6 月 1 日受付, 10 月 19 日受理) 